\title{
BOWEN'S DISEASE IN LEG - A RARE OCCURRENCE
}

Gowri Sankar R , Prem Charles D², P. Viswanathan³, P. K. Kaviarasan 4 , P. V. S. Prasad ${ }^{5}$

\section{HOW TO CITE THIS ARTICLE:}

Gowri Sankar R, Prem Charles D, P. Viswanathan, P. K. Kaviarasan, P. V. S. Prasad. “Bowen's Disease in Leg - A Rare Occurrence". Journal of Evolution of Medical and Dental Sciences 2014; Vol. 3, Issue 09, March 3; Page: 2126-2130, DOI: $10.14260 /$ jemds/2014/2114

ABSTRACT: A 50 year old female presented with complaints of asymptomatic, raised skin lesion over left leg for the past two years, which on local examination revealed a single, localized, well defined, rounded plaque of $4 \mathrm{~cm}$. Clinically Bowen's disease was not suspected because of its rarity and also occurred in the unusual site. Biopsy was taken and sent for histo-pathological examination. In histopathological examination Bowen's disease was diagnosed. This case is highlighted to show the pathologist's help in making a proper diagnosis when atypical skin lesions are seen at unusual sites. INTRODUCTION: Most of the overt malignant conditions actually originate as microscopic lesions, which are designated as in-situ carcinomas. These in-situ carcinomas are typically noticed as intraepithelial lesions, most often seen in squamous cell epithelial lined tissue eg. oral mucosa, genitals, cervix and skin. In skin, the intra-epithelial carcinoma-in situ lesions may be Bowen's disease, Bowenoid papulosis or Erythroplasia of Queyrat. In the same way gastrointestinal and urinary system also can show in-situ malignancies. Bowen's disease was first described by an American dermatologist John T Bowen in the year 1912. It is most commonly reported in sun exposed sites. It rarely occurs in patients with darkly pigmented skin. Bowen's disease is observed in skin and external genitals and is sometimes associated with arsenic poisoning and visceral carcinomas. Bowen's disease is a rare, persistent, progressive, intra-epithelial carcinoma, $8 \%$ of which will develop into an invasive squamous cell carcinoma. Treatment options are topical 5-fluorouracil, cryotherapy or surgical excision. Further a detailed clinical examination is needed along with supportive diagnostic aids to exclude the possibility of any internal malignancy. A wide excision is to be done to prevent invasive malignant tumor.

KEYWORDS: Bowen's disease, Leg, Intact basement membrane

CASE REPORT: A 50 years old female attended skin OP with asymptomatic, raised skin lesion over left leg for past two years which gradually increased in size for past one year and also there was an occasional bleeding for past six months. In the present patient arsenic ingestion was excluded by history. Extensive clinical history and diagnostic procedures didn't reveal any internal malignancy.

CUTANEOUS EXAMINATION: There was a single, localized, well defined, rounded plaque of $4 \mathrm{~cm}$ in size present on the left leg. The center of lesion was raised and contained flesh colored mass with peripheral hyper-pigmentation (Fig 1). The lesion bled on touch. Systemic examination was within normal limits. Clinico-pathological investigations were within normal limits. A diagnostic skin biopsy was done from the margin of the lesion and sent for histo-pathologic examination.

HISTO-PATHOLOGIC EXAMINATION: Histopathology examination revealed excess keratin with cells in the squamous epithelium exhibiting marked degree of dysplasia and anaplastic changes. (Fig. 2 \& 3). Squamous cells were disorderly arranged and basement membrane was found to be intact 
(Fig. 4 \& 5). Pigmentary incontinence was present along with lot of pigmented macrophages which was found in sub-epithelial zone (Fig. 6). Scattered mitotic figures were also present (Fig. 7).

DISCUSSION: Bowen's disease designates squamous cell carcinoma in situ of both sun exposed and non-exposed skin. This term is used for lesions that occur on the shaft and are not as grossly red as erythroplasia of Queyrat.1,2 Peak incidence is in the fifth and sixth decades, a decade earlier than erythroplasia of Queyrat. ${ }^{2}$ Gross examination shows crusted, sharply demarcated, scaly white plaques; rarely, they may form papillomatous lesions. Histologic differences from erythroplasia of Queyrat, such as hyperkeratosis and involvement of pilosebaceous units, are a function of the differing anatomic locations. ${ }^{1,3}$ Approximately five percent to ten percent of cases progress to invasive carcinoma. About one third of cases have been reported to develop cutaneous or extracutaneous malignant neoplasms; such a strong association with other cancers is not noted with erythroplasia of Queyrat.3,4

With a long duration, asymptomatic nature of the lesion a chronic granuloma was suspected. Among the chronic granulomas tuberculosis and sarcoidosis were considered. Atypical mycobacterial infection like swimming pool granuloma was also considered. On the other hand, deep fungal infections like sporotrichosis and chromomycosis were thought off. As Mantoux test was negative and potassium hydroxide preparation $(\mathrm{KOH})$ did not reveal any hyphae or spores, a diagnostic skin biopsy was done.

Histopathology showed classical Bowen's disease. Histologically squamous cell carcinoma was ruled out because of intact basement membrane and absence of pseudo-epitheliomatous hyperplasia. Patient was investigated and was found to be free from internal malignancy.

Even though the marked atypicality of the epidermal cells in Bowen's disease includes the cells of the basal layer, the border between the epidermis and dermis everywhere appears sharp, and the basement membrane remains intact. In a small percentage of cases of Bowen's disease, an invasive squamous cell carcinoma develops. The usual figure quoted is $3 \%$ to $5 \%$. The highest incidence given is $11 \% .^{5}$

The diagnosis of Bowen's disease was purely pathological as leg was an uncommon site for Bowen's and it occurs normally on sun exposed areas. The lesion was excised in-toto and follow up after one year did not reveal any relapse at the site.

In refractory Bowen's disease invasive squamous cell carcinoma is to be suspected.

\section{REFERENCES:}

1. Kaye V, Zhang G, Dehner LP et al. Carcinoma in situ of penis: Is distinction between erythroplasia of Queyrat and bowen's disease relevant? Urology 1990;36:479-82.

2. Young RH, Srigley JR, Amin MB et al. The penis. In tumors of the prostate gland, seminal vesicles, Male urethra and Penis. Atlas of tumor pathology. Third series, Fascicle 28. Washington, DC, Armed Forces Institute of Pathology, 2000;403-487.

3. Graham JH, Helwig EB. Erythroplasia of Querat: a clinicopathologic and histochemical study. Cancer 1973;32:1396-1414.

4. Callen JP, Headington JT. Bowens and non Bowen's squamous intraepithelial neoplasia of the skin: relationship to internal malignancy. Arch Dermatol 1980;116:422-26. 
5. Walter F. Lever. Histopathology of the skin: In: David E Elder, Rosalie Elenitsas, Bernett L. Johnson, George F. Murphy eds. Lever's Histopathology of the skin., Lipincott Williams \& Wilkins, Ninth edn, 2004:827.

\section{EQUIPMENT USED:}

Nikon Coolpix 8400.

' $\mathrm{X}$ ' denotes the power of the objective.

Stain used - H \& E.

\section{MACROSCOPIC PICTURE}

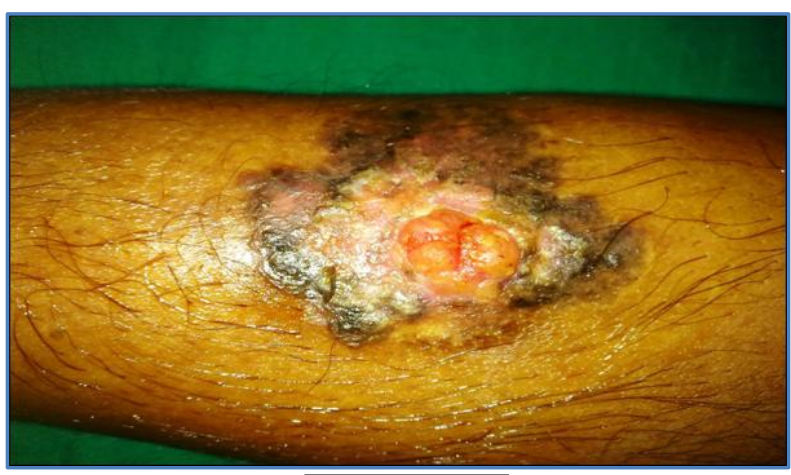

Figure 1

\section{MICROSCOPIC PICTURES}

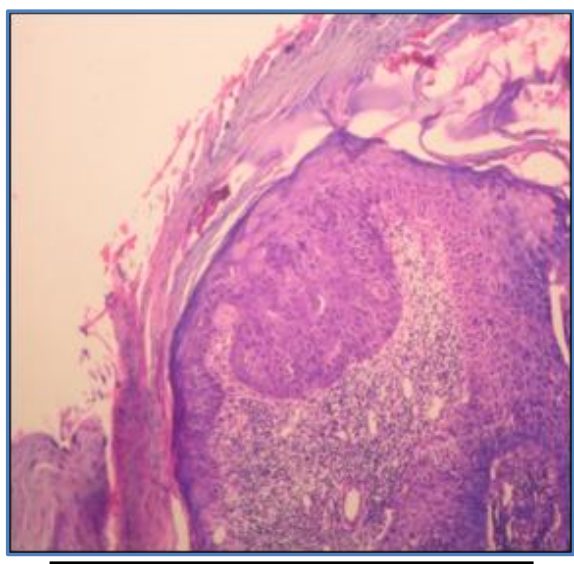

Fig. 2: H \& E stained $4 x$

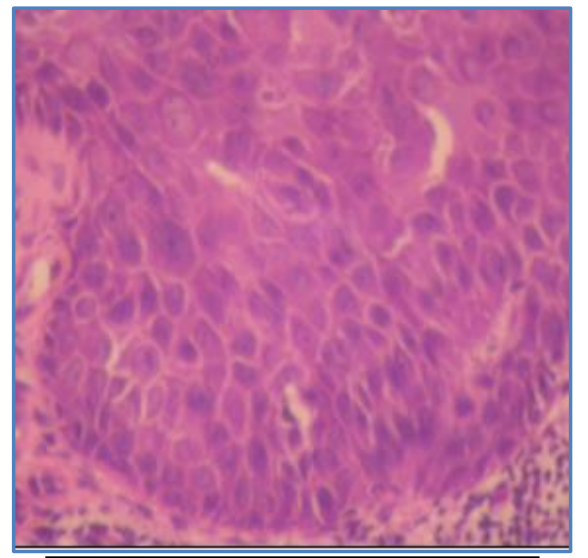

Fig. 3: H \& E stained $40 \mathrm{x}$

Excess keratin, cells in the squamous epithelium exhibits marked degree of dysplasia and anaplastic changes. There is disorderly arrangement of squamous cells. 


\section{CASE REPORT}

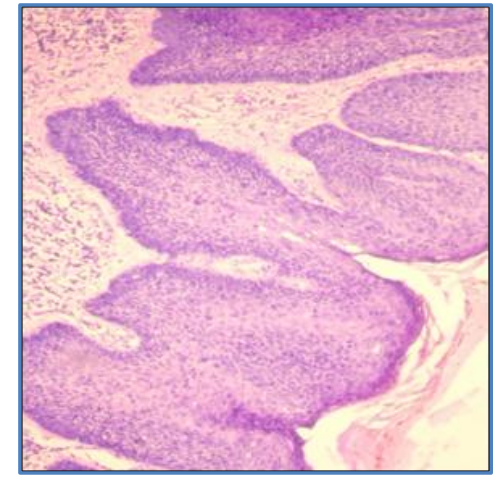

Fig. 4: H \& E stained $10 \mathrm{x}$

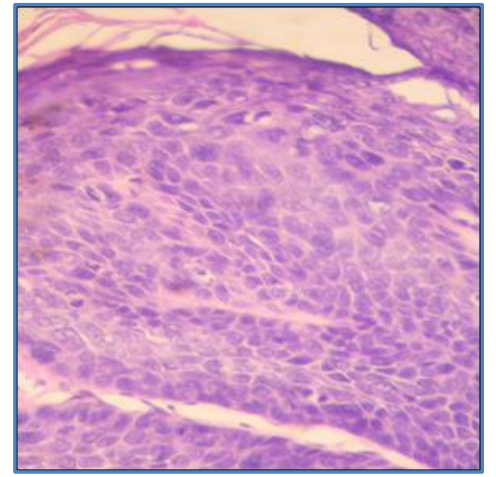

Fig. 5: H \& E stained $40 \mathrm{x}$

Disorderly arrangement of squamous cells and there is no breach in basement membrane.

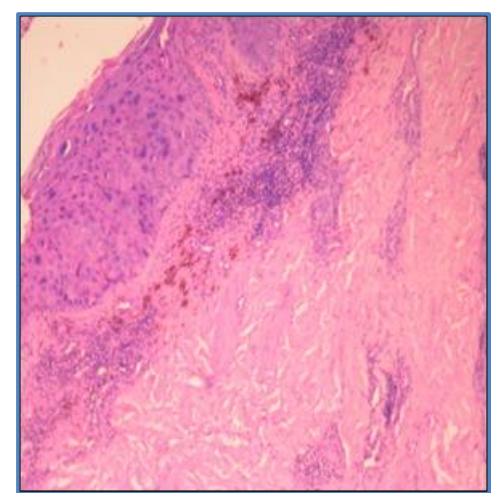

Fig. 6: H \& E stained $4 x$

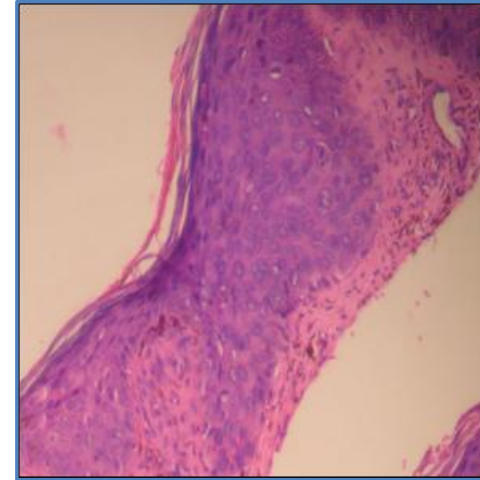

Fig. 7: H \& E stained $10 \mathrm{x}$

Pigmentary incontinence and pigmented macrophages in sub-epithelial zone. Scattered mitotic figures present. 


\section{AUTHORS:}

1. Gowri Sankar R.

2. Prem Charles D.

3. P. Viswanathan

4. P. K. Kaviarasan

5. P. V. S. Prasad

\section{PARTICULARS OF CONTRIBUTORS:}

1. Post Graduate, Department of Pathology, Rajah Muthiah Medical College, Annamalai University.

2. Post Graduate, Department of Pathology, Rajah Muthiah Medical College, Annamalai University.

3. Professor, Department of Pathology, Rajah Muthiah Medical College, Annamalai University.

4. Professor, Department of Dermatology Venereology Leprology, Rajah Muthiah Medical College, Annamalai University.
5. Professor and HOD, Department of Dermatology Venereology Leprology, Rajah Muthiah Medical College, Annamalai University.

\section{NAME ADDRESS EMAIL ID OF THE} CORRESPONDING AUTHOR:

Dr. P. Viswanathan,

Professor, Department of Pathology,

Faculty of Medicine,

Rajah Muthiah Medical College,

Annamalai University,

Chidambaram - 608002

Tamilnadu, India.

E-mail: drpviswanathan2013@gmail.com

Date of Submission: 04/02/2014.

Date of Peer Review: 05/02/2014.

Date of Acceptance: 14/02/2014.

Date of Publishing: 25/02/2014. 